\title{
Shell keeps its options open for disposing of Brent Spar
}

\section{Boost for Japanese centres of excellence in new grant scheme}

London. The Brent Spar oil platform could still end up at the bottom of the Atlantic Ocean if an environmentally safer alternative is not found, according to officials from Shell, the Anglo-Dutch oil company.

One month after Greenpeace compelled the oil company to abandon sinking the disused 14,500-tonne North Sea oil platform 150 miles out in the Atlantic, a Shell spokeswoman confirmed that deep-water disposal remains on the agenda.

"Nothing is being ruled out," says Jenny Weller. "We will be going back to the drawing board. We will consider all the available options and then choose the environmentally friendliest."

The British government, which endorsed Shell's decision in October 1994 to pursue deep-water disposal of Brent Spar as the 'best practicable environmental option', says it still supports the idea. Tim Eggar, a minister at the Department of Trade and Industry, said two weeks ago that the company must provide convincing arguments to support any change of plan.

Speaking at a parliamentary briefing, Eggar described the Greenpeace campaign to scupper deep-sea disposal as "dangerous" and "irresponsible", and urged Shell not to change its policy.

The briefing was organized by the government-funded Natural Environment Research Council (NERC), which, along with the University of Aberdeen, has endorsed the deep-sea disposal option. John Krebs, the council's director, maintained that the "available scientific evidence" favoured deep-sea disposal.

The Brent Spar platform, according to figures released by Shell, contains 68,000 tonnes of a concrete ballast chemically similar to rust, 100 tonnes of a bituminous sludge and 30 tonnes of low-level radioactive scale. There are, in addition, small quantities of heavy metals and polychlorinated biphenyls, synthetic molecules similar in structure and action to DDT

The underwater release of these chemicals, says NERC, poses negligible long-term threats to marine life. The initial impact would affect an area equivalent to two football fields. The organisms affected would be relatively few and would include mainly small organisms such as threadworms, crustaceans and molluscs. "The biological community would be re-established within a few years," predicts Krebs.

Dismantling Brent Spar on land would release environmentally damaging wastes not encountered in the deep-sea option, he says. In addition, the environmental consequences of leaks from the platform or accidental sinking during a towing operation

\section{IMAGE \\ UNAVAILABLE \\ FOR COPYRIGHT REASONS}

No resting place: deep-sea disposal remains a possibility, backed by the UK government.

would be far greater in shallow waters than in the deep ocean.

But this overall view is still disputed by Greenpeace, whose campaign highlighted the imprecise estimates (also acknowledged by NERC) of the quantities and toxicity of materials contained on the oil platform, as well as a lack of understanding of the deep sea environment.

Paul Johnston, a researcher at the Greenpeace Research Laboratories at the University of Exeter, says he welcomes moves announced by Shell last month for an independent inventory of Brent Spar's contents. But he suggests that a similar, comprehensive assessment be carried out of the impact on marine flora and fauna of the release of chemicals from the platform.

"At present there is very little empirical data on the effects of the proposed disposal on deep sea ecosystems," says Johnston.

Deep-sea disposal of Brent Spar, may lead to similar disposal of 50 deep-water oil installations in UK offshore waters that are next in line for decommissioning, Johnston says. "No one knows what effect this would have on the marine environment."

Greenpeace favours land-based decommissioning of oil rigs, explains Johnston, as facilities and methods for disposing, recycling and de-toxifying oil-industry waste are well-established in many parts of the world.

Brent Spar is now anchored at Erfjord in Norway, awaiting Shell's next move, which is likely to be later this year. Shell has, in the meantime, accepted Greenpeace's offer, along with that of "other bodies and environmental groups", to help develop an alternative disposal plan.

Ehsan Masood
Tokyo. Japan's Ministry of Education, Science and Culture (Monbusho) last week announced the first winners of substantial research grants under a new scheme intended to cultivate national centres of excellence within Japan's universities.

Grants worth about 300 million yen (over $\$ 3$ million) a year for five years were awarded to groups of researchers at Tokyo, Kyoto, Osaka, Nagoya and Hitotsubashi universities, and at Tokyo Institute of Technology. The six were chosen after a strongly contested competition that had attracted 194 applications.

The grants mark a historic departure from the ministry's traditional approach of spreading grant money relatively evenly and thinly - throughout the university system. They also indicate where some of the best research in Japan is being carried out.

The value of each grant greatly exceeds that of the ministry's 'special distinguished' and 'priority' grants, up to now Monbusho's most coveted awards. All have been awarded to teams working on research in science and technology, except for one on economics at Hitotsubashi University.

A team of about 60 researchers at Kyoto University, for example, headed by Shigetada Nakanishi of the Institute of Immunology, has been awarded 280 million yen in its first year to explore principles and molecular mechanisms of higher-order biological systems. The team, which includes a large number of graduate students, plans combining study of the nervous and immune systems with research on development and intracellular signal transduction mechanisms.

Another team made up of nine faculty members at Tokyo University, and headed by Katsuhiko Sato of the physics department, will receive 320 million yen to study the origin of the Universe. Ryoji Noyori of the chemistry department of Nagoya University will lead a team including 10 faculty members, and over 40 graduate students and postdoctoral fellows, in the synthesis and study of chiral substances.

Kenichi Iga, director of the Precision and Intelligence Laboratory at Tokyo Institute of Technology, plans to develop novel parallel optoelectronic systems with a team of nearly forty faculty members, graduate students and postdoctoral fellows.

Finally, another team of researchers led by Kenji Sobue of Osaka University medical school has been awarded support to pursue the ambitious goal of elucidating the whole picture of signal transduction both within and outside cells. The team's aim is to understand the pathogenesis of and discover new treatments for diseases such as cancer, AIDS, and arthritis.

David Swinbanks 